\title{
Part of the problem or of the solution? The involvement of religious associations in immigrant integration policy
}

\author{
Astrid Mattes ${ }^{1, *}$ \\ 1 Department of Political Science, University of Vienna, Austria \\ * E-Mail: astrid.mattes@univie.ac.at
}

\begin{abstract}
Across Europe we see faith-based organizations (FBOs) getting involved in the policy field of immigrant integration. The interweaving of the policy fields of religion politics and immigrant integration is particularly delicate in systems of religionstate cooperation. Here, FBOs and state actors build on each other to fulfil certain tasks. This paper explores how FBOs are involved in the field of immigrant integration and which techniques of government are being used. Drawing on empirical case studies from Austria, Germany and Switzerland, the paper shows that religious communities fulfil multiple roles as civil society actors, as religious representatives or as migrant associations. While similarities occur due to comparable structures and institutions, observed differences are the consequence of different constellations of suspicion and trust between FBOs and state actors.
\end{abstract}

\section{Keywords}

Immigrant integration politics, religious diversity, governance, governmentality, Islam in Europe

\section{Teil des Problems oder Teil der Lösung? Die Einbindung von Religionsgemeinschaften in Integrationspolitiken}

\section{Zusammenfassung}

In vielen Staaten Europas lässt sich eine zunehmende Einbindung religiöser Verbände in das Feld der Integrationspolitik beobachten. Diese Einbindung ist insbesondere in so genannten Systemen hinkender Trennung relevant, in denen Staaten eng mit Religionsgemeinschaften zusammenarbeiten. Dieser Beitrag geht der Frage nach, wie religiöse Verbände in Integrationspolitiken eingebunden sind und welche Techniken des Regierens dabei zum Tragen kommen. Empirische Fallstudien zu österreichischen, deutschen und schweizerischen Integrationspolitiken zeigen, dass religiöse Verbände multiple Rollen erfüllen: Sie agieren als zivilgesellschaftliche Akteure, als religiöse Repräsentanten und als MigrantInnenorganisationen. Während sich Ähnlichkeiten aus den vergleichbaren institutionellen Settings ergeben, können Unterschiede als Konsequenz unterschiedlicher Konstellationen von Misstrauen und Vertrauen zwischen religiösen und staatlichen Akteuren verstanden werden.

\section{Schlüsselwörter}

Integrationspolitik, religiöse Diversität, Governance, Gouvermentalität, Islam in Europa

\section{Acknowledgement}

I want to thank Sieglinde Rosenberger for her helpful comments on a previous version of this article. Her analytical way of thinking, her ability to be critical beyond the sake of criticism and her fine sense for the issues of our time are always inspiring.

The author has declared that no competing interests exist. 


\section{Introduction}

Migration inflows are one of the main reasons for religious diversification in contemporary European societies. At the same time, the relatively young policy field of immigrant integration became a central stage for political debates on religion, especially minority religions (Brunn 2012). Reasons for this focus on religion are manifold and issues range from identity politics (Mattes 2015) and security debates (Rodatz/Scheuring 20II) to practical aspects of state-religion relations (Klinge 2012). As a result, these policies address faith-based organizations $(\mathrm{FBOs})^{\mathrm{I}}$ as part of the policy problem and at the same time involve them in attempts at solutions. While FBOs are often the subject of political debate, they then become actors in the field of immigrant integration. Considering the "return of religion" to the political sphere (Casanova 2OI3; Foret/Itçaina 2OI2), immigrant integration is a fruitful area to understand how and why religious associations become increasingly involved in the politics of secular states.

This paper is guided by the question how faith-based organizations are involved in immigrant integration policy. To understand differences between the studied cases, I ask which discursive governing techniques can be identified within the roles religious associations fulfill. Drawing on document analysis and semi-structured interviews with religious and bureaucratic actors, the empirical basis of this study allows a thick description of the involvement of FBOs in Austrian, German and Swiss immigrant integration policies. The paper analyses processes of governance of religion in immigrant integration policies, followed by a critical reflection on the findings through the lens of governmentality.

Findings reveal that faith-based organizations fulfil multiple roles in the field of immigrant integration policy. Depending on the specific religion and a country's governance of diversity, they are involved as civil society actors, as religious representatives or as migrant associations. The comparative perspective identifies clear differences in immigrant integration policy between Germany, Austria and Switzerland, particularly with regards to Islam. Austria involves its recognized Islamic religious community mainly as a religious representative, German Islamic associations are most broadly involved and fulfil multiple roles, while Swiss Islamic associations are hardly involved at all. This can be understood by looking at the governmentality of religion in the context of immigrant integration: The notion of government through suspicion and trust (see Ragazzi 20I6), which is linked to discourses on Islam and migration, enables to understand different outcomes in three similar cases.

I Religious associations and faith based organizations are used synonymously to refer to religious organizations independent from their legal status. Religious communities is used to refer to religious groups recognized in law.
The paper proceeds as follows: First, the scholarly debate on immigrant integration and religious pluralism will be reviewed to name areas of involvement of FBOs identified in the literature. Second, the theoretical framework of this paper will be presented, drawing on the governance of diversity literature (2), the notion of governmentality and the benefits of combining those concepts (3). This is followed by a brief case description (4) and an overview of material and methods (5) for the empirical study presented in section 6, which discusses the empirical results against the backdrop of the theoretical framework.

\section{Governing diversity: linkages of immigrant integration and religion}

Immigrant integration and religious diversity are two policy fields that have been subject to intensive research for about two decades and the body of literature keeps growing. Immigrant integration is a relatively young policy field, with often changing structures (Rosenberger/Gruber 2016). The involvement of religion in this policy field is even younger (Allievi 2005), but became a central aspect of many European immigrant integration policies. Other immigrant integration issues, such as the inclusion into the labour market or questions of language proficiency and education, target the individual level and primarily concern newcomers. Religion, by contrast, is a category of "deep diversity" (Galston 1995) which liberal states tolerate per definition. Therefore, as Rogers Brubaker argues, religious diversity has strongest implications for the political accommodation of difference $(2013, \mathrm{I})$.

Within the massive literature on these implications, we can identify three different areas where FBOs become involved in immigrant integration policy. I subsume these three areas under the terms accommodation and establishment, adjustment and improvement, and implementation and enforcement.

By establishment and accommodation I refer to multilevel processes, comprised of "constitutional, legal, political, cultural, administrative" aspects (Bader 2007a, 202). Although religion politics is a separate policy field in most states, equipped with its own institutions and bureaucratic specialists, the broader establishment of minority religions has become central to many immigrant integration policies. As Brunn has shown, this is the case in laicist republican France as well as in multicultural Britain and ethnic Germany (2012). Studies on the establishment of religions focus on the ways of accommodation (Fetzer/Soper 2004; Mattes et al. 2016), the processes of negotiation for establishment (Klinge 2012; Maussen 2009) and 
normative questions of extent and limits for minority religious claims (Tatari 2009; Mookherjee 20I0).

I use the terms adjustment and improvement to refer to state attempts to influence religious practices, beliefs or structures. Turner wrote in this context about a "strategy of upgrading religion" that states apply to make certain religions compatible with liberal democratic regimes (2007, I24). Political influences on faith-based organizations may take the form of legal regulations (e.g. laws on religious symbols and unwanted practices), soft policy measures (e.g. campaigns and various forms of dialogue) or of laying down conditions for cooperation with the respective FBOs. Recent research about adjustment and improvement of $\mathrm{FBOs}$ focuses on controversial practices and beliefs discursively related to Islam, such as forced marriage and honour killing (Korteweg/Triadafilopoulos 2013), or more general questions of values (Mattes 2015) and security (Haverig 20I2). The structures of FBOs are another central aspect of adjustment and improvement, as policies often aim at steering community formation among minorities (Lange/Schimank 2004).

The third area of involvement, the participation of FBOs in immigrant integration policy projects, is referred to as implementation and enforcement. Levent Tezcan describes how FBOs become "integration agencies" when policy measures build on "pastoral" elements $(2007,65)$. Religious authorities as role models and the training of multipliers within FBOs make use of the perceived moral authority of religious leaders (Aslan/ Windisch 2012). Authors observe "governing through communities" especially in terms of security politics (Ragazzi 2016). Religious infrastructures are also frequently involved in general integration policy implementation. This is primarily the case with long-established religious welfare organizations, which have a long history in providing services to guest workers and refugees, both independently and on behalf of public authorities (Klee 1972). In contrast, the involvement of minority FBOs in policy implementation and in the provision of general services to migrants is often rather symbolical (Thränhardt 2009).

The areas in which the involvement of FBOs in integration policies has been observed - accommodation and establishment, adjustment and improvement, implementation and enforcement - are highly interrelated. A rough differentiation between state actors, minority religious associations and established FBOs should help to understand these relations.

Accommodation and establishment is clearly a goal for many minority FBOs. Especially in systems of religion-state cooperation, legal establishment brings economic, political and legal benefits. The involvement in public policies also legitimizes associations (internally and externally) and allows to widen their scope of action. Here Bader describes an "autonomy dilemma" (2007a, 228f.), whereby FBOs aiming at official recognition and broader establishment face a trade-off between privileges and political influences. Negotiation for establishment further requires a certain organizational structure and forces FBOs to develop effective representation and leadership.

State actors have several interests in influencing religious associations. First, systems of religion-state cooperation build on privileged partnerships with at least church-like structured FBOs. And while all liberal states have "to 'recognize' religion administratively and/or in legal or jurisprudential practice" (ibid., 226), these states are confronted with demands for considerable adaptation. Second, state actors aim at guaranteeing security and the functioning of public order and use their influence on FBOs for policing and control (Haverig 2012). Third, and inherently related to immigrant integration, is the need for agencies to implement policy measures. As discussed before in reference to implementation and enforcement, FBOs are suitable structures to provide services, to spread information and to enforce non-legally binding directives by means of social control.

Long-established FBOs are relevant actors in the field that are neither in need of approval nor subject to intense political influence. The still growing focus on religion within the field of immigrant integration potentially widens their scope of action and legitimizes their political influence. Both minority religious associations and state actors rely on their support in pursuing their goals (Baldas 2012).

\section{Governance and governmentality: How to under- stand religion in immigrant integration policy}

The description of actors and their activities follows the logic of governance analysis, an approach central to the scholarly debate on religious diversity (Bader 2007b; Bramadat/Koenig 2009; Griera 2016). While governance has become a fashionable and widely applied term, its meanings differ from one research area to another. For the field of religious diversity, governance usually refers to internal and external implications of various forms of regulating religion. Much broader than the concept of government, governance includes "those mechanisms of action coordination that provide active intentional capacities to regulate, including co-regulation and selfregulation" (Bader 2007b, 30). Typical research questions ask how state authorities, other political actors and governmental/legal regimes influence organized religion and vice versa. Thus, governance perspectives in the field of religious diversity are not limited to governmental action. Analytically though, it implies the perspective of a "governor" addressing a policy problem, although not necessarily impersonated by the government. 
This perspective leads to one of the strongest points of criticism of governance approaches. As Renate Mayntz argues, all governance approaches start from the (implicit) idea, that actors are interested in solving a (real or perceived) policy problem and set actions accordingly (2005). Other motives are largely ignored, so governance approaches often suffer from a "relative blindness towards phenomena of power and rule" (Höppner/Nagl 2009, 9). An approach that explicitly aims at understanding non-direct forms of power and underlying mechanisms is the concept of governmentality. Introduced by Michel Foucault (1977/2000), governmentality is a system of thinking of "how to conduct conduct" (Gordon I99I, 48). Nikolas Rose, who pursued the thought of governmentality, emphasizes that "the activity of government is inextricably bound up with the activity of thought", that the analysis of processes of governing requires "attention to the conditions under which it becomes possible to consider certain things to be true" (Rose I999, $7 \mathrm{ff}$ ). Similarly to Carol Bacchi's practical "What's the problem - Approach" (2009), a governmentality perspective is interested in the question how a situation is identified and becomes perceived as a policy problem in need of a solution. While governance aims at a realist analysis of relations and regulations between political actors in a field, governmentality aims to understand the emergence of certain "regimes of truth" (Rose I999, I9) and the resulting ways of exercising power.

While mapping actors and their roles within a field follows the logic of governance analysis, it is the perspective of governmentality that allows critically questioning the terms of their involvement. As Rose puts it, governmentality is "diagnostic rather than descriptive" (ibid.). Here lies the strength of combining governance and governmentality perspectives: scholars can apply diagnostic practices in addition to thick descriptions of their cases. This paper aims to do so by applying a twostep approach: First, processes of governance of religion in immigrant integration policies are analysed. This is followed by a critical reflection on the findings through the lens of governmentality, taking into account discursive techniques of governing. As many authors have shown (Flynn 2002; Corbridge 2005; Shore 20II), the combination of governance and governmentality - two approaches to analytically capture the activity of governing - can be fruitfully combined.

This combination of theoretical approaches is applied in a study on three similar cases. The following section introduces and contextualizes the cases of Austrian, German and Swiss immigrant integration policies.

\section{Three similar cases: Religion and immigrant integration in Austria, Germany and Switzerland}

In terms of immigration history, post-war Germany, Austria and Switzerland share many similarities. Guest worker regimes were established and workers from Eastern and Southern Europe came on a rotation principle. None of the countries anticipated the significant number of people who decided to stay permanently, as neither Austria nor Germany and Switzerland saw themselves as countries of immigration. Restrictive migration and integration policies were a consequence of the denied acceptance of the permanence of migration inflows. The three countries are classified as restrictive migration regimes and "ethno-cultural" models of citizenship (Bertossi/Duyvendak 2012). Migration inflows also originated mainly in the same countries, namely Turkey and former Yugoslavia (in addition to inflows from EU member states).

Immigrant integration politics in the countries under observation developed in similar manners, despite certain decisive differences, mostly stemming from varying degrees of federalism or centralization respectively. In all three countries policy makers at national level did not make any efforts for long-term integration up until the I990s (Ruedin et al. 2015; Bommes/Kolb 20I2; Mourão Permoser/Rosenberger 20I2). When immigrant integration evolved as a policy field, policy responsibility was spread across different governmental actors and offices. In the 200os, claims for a re-location of the cross-sectional policy agenda to a discrete governmental office for integration were frequently heard: Germany shifted policy responsibility for immigrant integration to a State Minister in the Federal Chancellery in 2005. In Austria, the State Secretariat for Integration, founded in $201 \mathrm{I}$ and located in the Ministry of interior, was the first institutionalization of immigrant integration at governmental level. In 2013 this responsibility shifted to the Ministry of Foreign Affairs, Integration and Europe. In Switzerland the Federal Office for Migration became a State Secretariat for Migration in 2OI4. The changing institutional setting was accompanied (and partially preceded) by the development of coordinated policy programmes at national level. Germany started this process in 2005 with an Integration Summit that resulted in the publication of a National Integration Plan (NIP). Austria consulted experts and stakeholders in an Integration Platform in 2007, and introduced both the Expert's Council for Integration and the National Action Plan for Integration (NAP) in 20IO. Swiss immigrant integration policy at federal level started in 20oI with so-called Focus Programmes for integration projects. The legal basis for current policies is the Foreigners Act of 2005. Following a 20Io governmental report, immigrant integration policy was modified into a new federal coordination strategy. 
In terms of religion-state regimes, the countries are classified as "systems of cooperation" (Minkenberg 2003), allowing for special treatment of selected, officially recognized religious communities. In Austria official recognition is regulated by federal law (RGBl. Nr. 68/1874 I867), while in Germany and Switzerland Länder and Kantone (with the exception of laic Geneva and Neuchâtel, see Winzeler 2009, 77 ff.) grant recognition to religious associations in accordance with their respective constitutional settings. Austria, which has a long history of being inclusive towards religion, has the broadest establishment of religious communities (I 7 nationwide, see BKA 2016). For example, recognition of Islam was granted as early as I9I 2 during the Austro-Hungarian monarchy (Mattes/Rosenberger 20I4). Official recognition of religious communities in Switzerland and Germany varies between their federal states, reaching from more inclusive settings (such as Hamburg and Bremen in Germany or Basel in Switzerland) to states that only grant that recognition to Christian churches (such as Schwyz or Wallis in Switzerland). With the German Islam Conference (Deutsche Islam Konferenz, DIK), the Ministry of the Interior created a federal body for the coordination, negotiation and collaboration with Islamic associations in 2006. This platform had two declared goals, the broad establishment of Islam in Germany and the integration of Muslim immigrants and their descendants. While Austrian and Swiss governments also installed dialogue platforms for the interaction with Muslim representatives, neither the Dialogue Forum Islam, initiated by the Austrian State Secretariat for Integration, nor the Swiss governmental initative Muslim-Dialogue became a lasting element of integration or religion politics.

To sum up, in a long list of similarities we can identify two major differences: First, Austria has - unlike Germany and Switzerland - granted official recognition to Islam and also most other minority religions. Second, Swiss federalism is most pronounced, which results in a smaller scope of both immigrant integration policies and politics of religious diversity on the national level.

\section{Methods and material for the analysis of religion in immigrant integration policies}

The empirical study builds on immigrant integration policy documents at national level and qualitative semistructured interviews with policy-makers and religious representatives. These materials are used to a) map the structures of involvement of FBOs in immigrant integration policy, b) describe the multiple roles of FBOs in immigrant integration policy, and c) critically reflect on the discursive techniques and subject constructions implied in the involvement of FBOs.
The collection of policy documents comprises national integration policy plans, major documents released by integration advisory councils, the policy output of platforms specifically dealing with the integration of Islam and lists of publicly funded integration policy projects issued between 2005 and 2015, a period that covers most major developments in the policy field. A detailed listing of documents can be found in the Appendix I. Interviews were conducted with high-level bureaucrats from governmental offices concerned with immigrant integration, members of integration councils and representatives of Muslim associations and Christian churches (see Appendix 2).

The empirical results presented in the following section stem from the qualitative analysis of documents and interview contents, coded in a two-stage coding procedure. First, actors, their relations and positions within the policy field, as well as their occurrence in different immigrant integration policy contexts, were coded based on a codebook derived from literature on governance of religious diversity (Bader 2007a). In a second step, subject constructions and discursive strategies were captured by a codebook following Carol Bacchi's What's the problem-Approach (Bacchi 2009) (see Appendix 3).

\section{Integrating religion, religions that integrate? Empirical results from immigrant integration politics}

\section{a) Mapping the field: Structures of involvement}

The document analysis focused on the involvement of FBOs and allowed identifying structures of policy involvement: religions as stakeholders (members of integration boards and councils), integration fora specific to religion, religions in policy development and religions in policy measures; (see Fig. I)

In Austria structural involvement is limited. Boards and councils rarely involve religious representatives. In the Integration Council the established Christian welfare organizations Caritas (Catholic) and Diakonie (Protestant) are listed as NGOs with other large non-religious initiatives. As described above, in 20I2/I3 Austria had a forum for dialogue with Islam. This was however transformed into a broader religious dialogue that included all recognized religions, established in the Federal Chancellery (BKA), no longer concerned with immigrant integration (see DOC ATIO). Caritas and Diakonie were also involved in the Steering Group for the development of the NAP. So called "expert talks" also involved religious actors from recognized Christian-Orthodox, Jewish and Islamic communities in this policy process, even though their involvement was limited to the field of inter-cultural 
Figure 1: Structures of policy involvement

\begin{tabular}{|c|c|c|}
\hline \multirow{3}{*}{$\begin{array}{l}\text { Stakeholder: } \\
\text { FBOs as members in councils, boards, etc. }\end{array}$} & AT: & Integration Council \\
\hline & DE: & Integration Council \\
\hline & $\mathrm{CH}:$ & Confederate Commission for Questions of Migration (EKM) \\
\hline \multirow{4}{*}{$\begin{array}{l}\text { Target group Muslims: } \\
\text { Integration fora specific to religion }\end{array}$} & AT: & Islam Dialogue \\
\hline & & Dialogue of Religions at Federal Chancellery \\
\hline & DE: & German Islam Conference \\
\hline & $\mathrm{CH}:$ & Muslim-Dialogue \\
\hline \multirow{4}{*}{$\begin{array}{l}\text { Policy development: } \\
\text { FBOs involved in policy formulation }\end{array}$} & AT: & Steering group on NAP \\
\hline & & Expert groups on NAP \\
\hline & DE: & Integration summits \\
\hline & $\mathrm{CH}:$ & no involvement at national level (aside from EKM) \\
\hline \multirow{6}{*}{$\begin{array}{l}\text { Policy projects: } \\
\text { FBOs carry out integration projects }\end{array}$} & AT: & State funded integration projects (BMI/SSI/BMEIA) \\
\hline & & NAP measures \\
\hline & DE: & State funded integration projects (BAMF) \\
\hline & & NIP self-commitments \\
\hline & $\mathrm{CH}:$ & Programmes of national relevance (EKM) \\
\hline & & Cantonal integration programs (EJPD/SEM) \\
\hline
\end{tabular}

dialogue (see DOC AT4). The listed examples of policy measures within the National Action Plan for Integration include some implemented by Catholic, Protestant and Islamic associations (see DOC AT7). Still, the big Christian welfare organizations are most involved in policy measures. In 2015, for example, Caritas and Diakonie carried out about 20 percent of all integration projects funded by the Ministry for Integration (see DOC ATI4). The recognized Jewish and Islamic communities received occasional funding for carrying out immigrant integration projects.

In Germany stakeholder involvement varied. Between 2009 and 20I4, an integration council included representatives of Christian-Orthodox, Jewish, Islamic and other FBOs (see Doc DE2). A central way of involving religion in German immigrant integration politics is the German Islam Conference (DIK). Established in 2006 , its mandate was renewed for the $3^{\text {rd }}$ time in 2014. During the three periods (analogous to the governmental terms), the DIK changed its structure, its participant composition and its priorities. Some of the Islamic associations involved in the DIK were also part of immigrant integration policy development. The so-called integrations summits that prepare the work on the National Integration Plan (2007) and its succeeding documents included Islamic, Christian-Orthodox, Catholic as well as Protestant and Jewish representatives. Regarding the involvement of FBOs in policy measures, the structure resembles the Austrian setting: Established Christian welfare organizations carry a large proportion of immigrant integration projects (around I5 percent). Around two percent of immigrant integration projects are carried out by Islamic associations (see DOC DEI2).

In Switzerland an advisory board at national level, the so-called Eidgenössische Kommission für Migrationsfragen (EKM), includes representatives from the Catholic and Protestant churches as well as an Imam. A forum for Islam-specific dialogue with state authorities (Muslim-Dialog) was initiated in 2010, but did not last very long. In $201 \mathrm{I}$ the federal government decided to end this platform and limit dialogue activities to the level of cantons. This is a typical feature of Swiss immigrant integration policy: National immigrant integration policy activities are limited by a strong sense of subsidiarity. Also, immigrant integration policy development is mostly left to cantonal structures. At national level no deliberative policy development processes take place, therefore there is also no direct involvement of religions in national policy formulation. Of the projects (co-)financed by national agencies a small proportion is carried out by Christian associations, most prominent among them the Catholic Caritas (see DOC CHI4). Unlike in Austria and Germany, many integration projects are carried out by private foundations, universities or companies focused on social work. Faith-based organizations play a smaller role overall. However, this is only true of the national level. Cantonal immigrant integration funding was not analysed systematically. 
To sum up: Established Christian welfare organizations are most strongly involved in all three countries' immigrant integration policies. Also, Islam has a specific role, as the three states have established fora to debate the integration of Islam. Other FBOs are only occasionally involved in the structures of immigrant integration. These observations can be further specified when we include the areas of immigrant integration that $\mathrm{FBO}$ are involved in.

\section{b) FBOs' multiple roles: areas of involvement}

Within these structures of involvement, FBOs are ascribed and fulfil multiple roles. From the literature we know the previously discussed three different areas of religious involvement: accommodation and establishment, adjustment and improvement, implementation and enforcement.

Accommodation and establishment is not so much of an issue in Austria, where official recognition is granted to all major religious communities, including Islam. Clearly this is also the reason for the quick end of the Austrian Islam-specific forum. When issues of establishment and accommodation are discussed, then rarely in the context of immigrant integration. The negotiation of Islam law in 2015 states an exception: Here, the Minister for Integration, Sebastian Kurz, publicly appeared as governmental actor in charge (OTS 2015). Policy responsibility for religion-state relations, however, lies with the Kultusamt, located in the Federal Chancellery. In Germany establishment and accommodation, especially of Islam, are at the centre of integration politics. The DIK also structurally combines immigrant integration and accommodation of Islam. Although a responsibility of the Länder, this platform of the national level debates preconditions for establishment, often in relation to issues of immigrant integration. In Switzerland, where legal establishment and most aspects of accommodation are cantonal responsibilities, accommodation is hardly negotiated at federal level. In the few instances where this is the case, accommodation is clearly interwoven with immigrant integration, as in the case of the Muslim-Dialogue.

We find instances of adjustment and improvement of religious structures and contents in all three countries, almost exclusively in reference to Islam. In Austria this is not a dominant pattern of immigrant integration policy, but it occurred in the context of the Dialogue Forum Islam, where common values were briefly debated (see DOC ATr6), and in the above mentioned Islam Law, negotiated by the Minister for Integration. The Islam Law significantly changes existing structures and explicitly states that "There must be a positive basic attitude towards society and state" (Islam Law 2015, § 4. (3)). In Germany the DIK aimed at contributing to the de- velopment of new structures for Muslims in Germany, more comparable to those of the established Christian churches (INT DE6). Religious practices and beliefs are subject to adjustment and improvement, when Muslim associations are required to commit to common values (e.g. DOC DE2I), confirm their loyalty to the constitution (e.g. DOC DE7) and condemn practices like forced marriage (e.g. DOC DE4). Swiss immigrant integration policies hardly refer to religious structures and contents. Unwanted practices like forced marriage are addressed extensively, but not in relation to religion. The Swiss Muslim-Dialogue report, however, begins with the dissociation of Muslim participants from terror, radical thoughts, ghettoization and human rights violations (see DOC CHI7). Structures were influenced only at cantonal level, and often indirectly, as an example from Kanton Zürich shows: Here an association wanted an Islamic cemetery. When the cantonal government refused to negotiate with a single association, the VIOZ, a cantonal umbrella organization for Zurich Islamic associations evolved (INT CH3, INT CH5).

Implementation and enforcement of immigrant integration policy via FBOs is the third area of involvement identified from the literature. In Austria general integration projects (not related to religion) are only implemented by Christian FBOs. The rare projects carried out by Jewish and Islamic FBOs are for the most part either about their respective religion or about inter-religious dialogue and tolerance. In Germany non-Christian FBOs are also implementing general integration policy measures. The Turkish Islamic Union for Religious Affairs (DITIB) for example, is one of the organizations that offers the obligatory integration courses for newcomers (see DOC DEI2). Islamic associations were also involved in the sample measures listed in the NIP, referring among others to projects against forced marriage and domestic violence. Projects aimed at the integration of Muslims and Jews are even declared funding priorities (DOC DEI7). In Switzerland the role of religions in the implementation and enforcement of immigrant integration policies is generally limited. Of the projects that involve religion, most are carried by established Christian associations and have a general focus.

The combination of structures of involvement and areas of involvement allows differentiating between the various roles of $\mathrm{FBOs}$ in immigrant integration policies.

- Civil society actors: FBOs are responsible for the implementation of general integration policy goals such as language proficiency or social work. As civil society actors they might also become involved in integration councils as stakeholders alongside other NGOs.

- Religious representatives: FBOs are involved as religious representatives where they serve as represen- 
tatives of the religious needs of believers alongside other FBOs. Here FBOs might also negotiate accommodation and establishment. As religious representatives they are asked to implement integration projects on religion specific issues (e.g. inter-religious dialogue).

- Migrant organizations: FBOs are involved as representatives of an immigrated community, responsible for the integration of their members. Projects that involve FBOs in this role aim at the integration of their group members, often through practices of adjustment and improvement.

These roles can't be sharply differentiated and overlap in practice. It is possible, though, to identify tendencies to summarize the findings of this governance analysis:

The role of civil society actors is primarily fulfilled by established Christian welfare organizations. Only in Germany, other FBOs occasionally also take on this role. While the involvement of established Christian churches is limited to this field in all three cases, minority FBOs seem to have multiple other roles in immigrant integration. Typically, Austrian recognized Jewish and Islamic communities are involved as religious representatives. Islamic FBOs in Switzerland and Germany fulfil this role when establishment and accommodation are negotiated. In Austria FBOs are hardly involved as migrant associations. This role is primarily fulfilled by Islamic FBOs in Germany and partly so in Switzerland.

\section{c) Understanding differences: Looking at the govern- mentality of religion}

To better understand differences in the governance of religion in immigrant integration, it is useful to widen the view and discuss immigrant integration policy from the perspective of governmentality. Therefore we need to identify "lines of thought", of "acts and counter-acts" (Rose 1999, 2I). In terms of the involvement of FBOs in immigrant integration politics, this perspective is most fruitfully applied to the issue of Muslim integration, as the involvement of Islamic FBOs has to be seen against the backdrop of a polarized, politicized and mostly exclusionary discourse.

Islam has become discursively connected with security threats, patriarchy and anti-democratic regimes (Korteweg/Triadafilopoulos 2013). Muslim interview partners and interviewed policy-makers alike explicitly confirmed that these discourses influence their activities and scope of action. The observed 'adjustment and improvement' of Islamic FBOs is a good example of the complementarity of governance and governmentality: The commitment to rule of law and human rights demanded from Islamic FBOs in all countries can be understood as the attempt to secure their suitability as negoti- ating partners. Our interviews, however, did not confirm this. Swiss (INT CHI, INT CH2) and German (INT DE5) bureaucrats stated that these attempts are reactions to public and political discourses. All Muslim interviewees emphasized their frustration about repeated demands to publicly declare themselves as not illiberal. The thoughts behind these demands, namely the questionable loyalty of Muslims to rule of law and liberal norms, serves as a discursively produced "regime of truth" (Rose I999).

Following the logic of this regime of truth, trust and suspicion become central techniques of governing that allow understanding the differences observed between Austria, Germany and Switzerland. Here the concept of a suspect category (also suspect community) is crucial. The notion of suspect community was originally developed by Hillary in reference to anti-terror strategies regarding Northern Ireland. Pentazis and Pemberton, who applied the concept to British Muslims, define it as "a sub-group of the population that is singled out for state attention as being 'problematic"' (2009, 649). Ragazzi suggests that in this context "[...] the main techniques of government are those of 'empowerment', 'partnership' and 'community policing', which take their roots in the pro-active and self-management imperatives of neo-liberal governmentality" (2016, 734). Governing through (suspect) community is therefore not a simple discriminatory practice vis-à-vis Muslims, it only works if it is supported by (parts of) those to be governed. Here Ragazzi speaks of "trusted" Muslims (ibid.).

This interplay between suspicion and trust is equally found in the involvement of Islamic FBOs in immigrant integration policies. FBOs are interested in being trusted when they aim for establishment and accommodation. This makes them willing to trade off autonomy (e.g. tolerate adjustment and improvement) for the perspective of establishment (as described in Bader's notion of the "autonomy dilemma"). State actors, on the other hand, depend on the cooperation and trustworthiness of agencies to implement integration policy measures. The widest involvement then occurs where suspicion and trust are most balanced.

In Austria legal establishment is granted to Islam, so the perspective of "being trusted" does not serve as an incentive. The recent restrictive changes to the Islam Law might be viewed as an expression of suspicion by the current government and the result of a discourse that had come to a head. Another way to understand the restrictive outcome of this law are internal conflicts among different groups within the Islamic Religious Community in Austria that was involved in all steps of the legislation. However, the Austrian Islamic communities are not depended on the label "trusted". The legal setting guarantees them the comfortable role as established religious representatives and is in a figurative sense the legal expression of trust. Therefore Austrian 
Islamic communities do not need to prove themselves as possible civil society actors, nor can state actors expect them to willingly accept the role of a migrant organization. Involvement in immigrant integration is therefore limited to the role as religious representative.

In Switzerland regulations for legal establishment vary from canton to canton. What is more, as emphasized by Swiss interview partners, official recognition is hardly a realistic perspective for Islamic FBOs. Even if there was the political will to grant recognition, the perspective of a public referendum against it seems to scare all parties off (INT CHI, INT CH6). In immigrant integration policies, Swiss Muslims are not treated as "trusted" partners and suspicion clearly dominates. Suspicion by state actors in Switzerland is then further heightened by right-wing actors: They reply to any sign of trust towards Muslims with the threat of a referendum. Interviews have shown that Swiss Islamic FBOs aim for the role as religious representatives rather than that of civil society actors (INT $\mathrm{CH}_{3}$, INT $\mathrm{CH}_{5}$ ). This, however, is only a limited option as there is hardly any involvement of non-Christian FBOs in this role in Swiss immigrant integration policies. Christian interview partners even saw a more general suspicion against religion that also influenced their inclusion $\left(\mathrm{INT} \mathrm{CH}_{4}\right.$, INT CH6). Therefore Islamic FBOs are - if at all involved limited to the role of migrant organizations, responsible for the integration of their religiously defined members.

Especially in Germany, all interviewed Muslim representatives indicated that they hope for the role of civil society actors. Here the prospect of legal establishment is especially strong and according to all German interview partners, including bureaucrats, also a realistic perspective. German Muslims therefore have a strong need to be "trusted". This explains why German Islamic FBOs accept and embrace their role as migrant organizations, the manifold instances of adjustment, improvement and thereby expressions of suspicion. We then see why involvement in immigrant integration policy is broader in Germany than in Austria and Switzerland. Acts and counter acts strengthen the involvement in all three roles described, tying German Islamic FBOs closer and closer to the field of immigrant integration.

\section{Conclusion}

The governance analysis identified three roles fulfilled by FBOs: civil society actors, religious representatives and migrant associations. The degree to which FBOs fulfilled each of these roles varies between Austria, Germany and Switzerland. The perspective of governmentality allows including discourses and the notions of suspicion and trust. We can see how the interactions between state actors and Islamic FBOs in the field of immigrant inte- gration, documented in the governance analysis, depend on a specific "regime of truth". This helps to understand why Austrian Islamic FBOs are less involved, despite official recognition (mostly fulfilling the role of religious representatives), why German Islamic FBOs are strongly involved as migrant associations, as religious representatives and partly as civil society actors, and why Swiss Muslim associations are least involved. The techniques of government using suspicion and trust can be found across the borders of the studied countries. The outcomes of these techniques of government, however, vary as a result of different structures.

In the field of immigrant integration politics, both established and newer minority FBOs play a decisive role. While especially Islamic associations seek to be involved like established Christian FBOs, their involvement is hardly ever that of a civil society actor (unlike the role of Catholic and Protestant associations). It mostly remains limited and often tied to their perception as alien. The critique of involvement of minority religion in immigrant integration politics therefore is reminiscent of that of multiculturalism. When Muslims are addressed in immigrant integration politics, it might as well be seen as a strategy of "divide and rule" and a way to keep "them off serious policy agendas" (Vertovec 20IO, 85). Despite the fact that established Christian Churches and Muslim associations are all involved in the same field, their roles are very different. And while inclusion is a declared goal of all countries' immigrant integration policies, it is questionable if the involvement of religions contributes to it.

\section{Literature}

Allievi, Stefano (2005). How the Immigrant has Become Muslim, in: Revue européenne des migrations internationales, Vol. 2I(2), I35-I63.

Aslan, Ednan/Zsofia Windisch (2012). The Training of Imams and Teachers for Islamic Education in Europe. Vienna.

Bacchi, Carol Lee (2009). Analysing policy: what's the problem represented to be? Frenchs Forest, N.S.W.

Bader, Veit (2007a). Secularism or Democracy? Associational Governance of Religious Diversity, Amsterdam.

Bader, Veit (2007b). The Governance of Islam in Europe: The Perils of Modelling, in: Journal of Ethnic and Migration Studies, Vol. 33(6), 87I-886.

Baldas, Eugen (2012). Integration als Aufgabe verbandlicher Caritas, in: Jahrbuch für christliche Sozialwissenschaft, Vol. 35, 209-224.

BKA (2016). Gesetzlich anerkannte Kirchen und ReligionsgemeinschafteninÖsterreich:Kultusamt:Bundes- 
kanzleramt Österreich, Internet: https://www.bka. gv.at/site/4735/default.aspx (Zugriff: I8.8.20I6)

Bommes, Michael/Holger Kolb (2012). Germany, in: Christian Joppke/F. Leslie Seidle (eds.): Immigrant Integration in Federal Countries, Quebec, II3-I34.

Bramadat, Paul/Matthias Koenig (2009). International Migration and the Governance of Religious Diversity, Montreal.

Brubaker, Rogers (20I3). Language, religion and the politics of difference, in: Nations and Nationalism, Vol. I9(I), I-20.

Brunn, Christine (2012). Religion im Fokus der Integrationspolitik: ein Vergleich zwischen Deutschland, Frankreich und dem Vereinigten Königreich, Wiesbaden.

Casanova, José (20I3). Europas Angst vor der Religion, 2. Auflage, Berlin.

Corbridge, Stuart (2005). Seeing the State: Governance and Governmentality in India, Cambridge.

Fetzer, Joel S./J. Christopher Soper (2004). Muslims and the State in Britain, France, and Germany, Cambridge.

Flynn, Rob (2002). Clinical governance and governmentality, in: Health, Risk \& Society, Vol. 4(2), I55-I73.

Foret, François/Xabier Itçaina (20I2). Politics of Religion in Western Europe: Modernities in conflict? New York.

Foucault, Michel (2000). Die Gouvernementalität, in: Ulrich Bröckling (Hrsg.): Gouvernementalität der Gegenwart, Frankfurt am Main, 4I-67.

Galston, William A. (I995). Two Concepts of Liberalism, in: Ethics, Vol. I05(3), 516-534.

Gordon, Colin (I99I). Gouvernmental Rationality: an Introduction, in: Graham Burchell/Colin Gordon/Peter Miller (eds.): The Foucault Effect: Studies in Governmentality, Chicago, I-53.

Griera, Mar (2016). The governance of religious diversity in stateless nations: the case of Catalonia, in: Religion, State and Society, Vol. 44(I), I3-3I.

Haverig, Anika (2012). Managing Integration: German and British Policy Responses to the "Threat from Within" Post-200I, in: Journal of International Migration and Integration, Vol. I4(2), 345-362.

Höppner, Ulrike/Dominik Nagl (2009). Approaching understanding: governance and governmentality as concepts for the analysis of politics in (post-) colonial spaces, available at SSRN 2598077.

Klee, Ernst (1972). Caritas vor Gericht, in: Die Zeit. Internet: http://www.zeit.de/1972/I4/caritas-vor-gericht (Zugriff: I0.2.2016)

Klinge, Marcel (2012). Islam und Integrationspolitik deutscher Bundesregierungen nach dem II. September 200I. Eine Politikfeldanalyse der ersten Deutschen Islam Konferenz und ihrer Implikationen für die nationale Integrationspolitik. HumboldtUniversität zu Berlin. Internet: http://edoc.hu-berlin. de/dissertationen/klinge-marcel-2OI2-06-2I/PDF/ klinge.pdf (Zugriff: 22.5.20I3)

Korteweg, Anna/Triadafilos Triadafilopoulos (2013). Gender, Religion, and Ethnicity: Intersections and Boundaries in Immigrant Integration Policy Making, in: Social Politics: International Studies in Gender, State \& Society, Vol. 2O(I), I09-I36.

Lange, Stefan/Uwe Schimank (Hrsg.) (2004). Governance und gesellschaftliche Integration I. Aufl., Wiesbaden.

Mattes, Astrid (2015). Towards a universal religion? Symbolic boundaries in Austrian immigrant integration policies, in: Isabella Guanzini/Kurt Appel (eds.): Europa mit oder ohne Religion? II, Vienna, 219-240.

Mattes, Astrid/Julia Mourão Permoser/Kristina Stoeckl (20I6). Introduction: Institutional Responses to Religious Diversity, in: Interdisciplinary Journal for Religion and Transformation in Contemporary Society - J-RaT, Vol. 2(I), 2-II.

Mattes, Astrid/Sieglinde Rosenberger (2014). Islam and Muslims in Austria, in: Ines Michalowski/Marian Burchardt (eds.): After integration: Islam, conviviality and contentious politics in Europe, Wiesbaden, I29-I52.

Maussen, Marcel (2009). Constructing Mosques: The Governance of Islam in France and the Netherlands, Amsterdam School for Social Science Research.

Mayntz, Renate (2005). Governance als fortentwickelte Steuerungstheorie?, in: Gunnar Folke Schuppert (Hrsg.): Governance-Forschung: Vergewisserung über Stand und Entwicklungslinien, Baden-Baden, II-2O.

Mookherjee, Monica (20IO). Democracy, Religious Pluralism and the Liberal Dilemma of Accommodation, Dordrecht.

Mourão Permoser, Julia/Sieglinde Rosenberger (2OI2). Integration Policy in Austria, in: James Frideres/John Biles (eds.): International Perspectives. Integration and Inclusion, Montreal and Kingston, 39-58.

OTS (2015). Blümel: Sebastian Kurz hat mit Islamgesetz Meilenstein gesetzt, in: ots.at. Internet: http://www. ots.at/presseaussendung/OTS_2OI5O225_OTSO2O3/ bluemel-sebastian-kurz-hat-mit-islamgesetz-meilenstein-gesetzt (Zugriff: I8.8.2016)

Pantazis, Christina/Simon Pemberton (2009). From the "Old" to the „New“ Suspect Community: Examining the Impacts of Recent UK Counter-Terrorist Legislation, in: British Journal of Criminology, Vol. 49(5), 646-666.

Ragazzi, Francesco (2016). Suspect community or suspect category? The impact of counter-terrorism as 'policed multiculturalism', in: Journal of Ethnic and Migration Studies, Vol. 42(5), 724-74I. 
religion.orf.at (20I4). Bundeskanzler Faymann lädt zu Religionsdialog, Internet: http://religion.orf.at/stories/2659733/ (Zugriff: 18.8.2016)

RGBl. Nr. 68/1874 (I867). Gesamte Rechtsvorschrift für Gesetzliche Anerkennung von Religionsgesellschaften. Internet: http://www.ris.bka.gv.at/GeltendeFassung.wxe? Abfrage $=$ Bundesnormen $\&$ Gesetzes nummer $=10000006$ (Zugriff: 2.9.2013)

Rodatz, Mathias/Jana Scheuring (20II). 'Integration als Extremismusprävention`, in: Forum für kritische Rechtsextremismusforschung (Hrsg.): Ordnung. Macht. Extremismus, 163-190.

Rose, Nikolas S. (1999). Powers of freedom: reframing political thought, Cambridge, United Kingdom, New York.

Rosenberger, Sieglinde/Oliver Gruber (2016). Politikwandel durch Institutionalisierung? Die österreichische Integrationspolitik und das Staatssekretariat für Integration (2OII-2OI3), in: IPW Working Papers, Vol. 20I6(I), I-27.

Rosenberger, Sieglinde/Birgit Sauer (2013). Politics, Religion and Gender: Framing and Regulating the Veil, New York.

Ruedin, Didier/Camilla Alberti/Gianni D’Amato (2015). Immigration and Integration Policy in Switzerland, I848 to 20I4, in: Swiss Political Science Review, Vol. $2 \mathrm{I}(\mathrm{I}), 5^{-22 .}$

Shore, Cris (20II). 'European Governance' or Governmentality? The European Commission and the Future of Democratic Government, in: European Law Journal, Vol. I7(3), 287-303.

Tatari, Eren (2009). Theories of the State Accommodation of Islamic Religious Practices in Western Europe, in: Journal of Ethnic and Migration Studies, Vol. 35(2), 27I-288.

Tezcan, Levent (2007). Kultur, Gouvernementalität der Religion und Integrationsdiskurs, in: Levent Tezcan/ Monika Wohlrab-Sahr (Hrsg.): Konfliktfeld Islam in Europa, Soziale Welt. Baden-Baden, 5I-76.

Thränhardt, Dietrich (2009). Migrations- und Integrationspolitik: Vom Korporatismus zur inszenierten Verstaatlichung, in: Britta Rehder/Thomas von Winter/Ulrich Willems (Hrsg.): Interessenvermittlung in Politikfeldern, Wiesbaden, 156-172.

Turner, Bryan S. (2007). Managing religions: state responses to religious diversity, in: Contemporary Islam, Vol. I (2), I23-I37.

Vertovec, Steven (2010). Towards post-multiculturalism? Changing communities, conditions and contexts of diversity, in: International Social Science Journal, Vol. 6I(199), 83-95

Winzeler, Christoph (2009). Einführung in das Religionsverfassungsrecht der Schweiz, 2. Auflage, Zürich.

\section{Author}

Astrid Mattes (1988) is $\mathrm{PhD}$ researcher at the Department of Political Science at University of Vienna. She studied Political Science and Comparative Religious Studies in Vienna (Austria) and Limerick (Ireland) and spent research visits at the Universities of Lucerne (Switzerland) and Toronto (Canada). Her research interests include the fields of immigrant integration politics, challenges of pluralism, religious diversity, Islam in Europe and religion-state relations. Latest publication: Special Issue "Institutional Responses to Religious Diversity", Interdisciplinary Journal for Religion and Transformation in Contemporary Society, 2016 (I) (with Kristina Stoeckl and Julia Mourao Permoser). 


\section{Appendix}

\section{Appendix 1}

\begin{tabular}{|c|c|c|}
\hline Documents & Title & Author/Date \\
\hline DOC AT1 & Gemeinsam kommen wir zusammen & Bundesministerium für Inneres, 2007 \\
\hline DOC AT2 & $\begin{array}{l}\text { Integration in Österreich. Einstellungen } \\
\text { Orientierungen und Erfahrungen }\end{array}$ & Bundesministerium für Inneres, 2009 \\
\hline DOC AT3 & Arbeitsprogramm Expertenrat & Bundesministerium für Inneres, 2010 \\
\hline DOC AT4 & $\begin{array}{l}\text { Expertengespräche Nationaler Aktionsplan } \\
\text { Integration - Interkultureller Dialog I und II }\end{array}$ & Bundesministerium für Inneres 2010 \\
\hline DOC AT5 & Nationaler Aktionsplan Integration - Bericht & Bundesministerium für Inneres, 2010 \\
\hline DOC AT6 & Nationaler Aktionsplan Integration - Indikatoren & Bundesministerium für Inneres, 2010 \\
\hline DOC AT7 & $\begin{array}{l}\text { Nationaler Aktionsplan Integration - } \\
\text { Maßnahmenkatalog }\end{array}$ & Bundesministerium für Inneres, 2010 \\
\hline DOC AT8 & Integrationsbericht 2011 & Staatssekretariat für Integration, 2011 \\
\hline DOC AT9 & Integrationsbericht 2012 & Staatssekretariat für Integration, 2012 \\
\hline DOC AT10 & Integrationsbericht 2013 & Staatssekretariat für Integration, 2013 \\
\hline DOC AT11 & Integrationsbericht 2014 & $\begin{array}{l}\text { Bundesministerium für Europa, Integration und Äußeres, } \\
2014\end{array}$ \\
\hline DOC AT12 & Integrationsbericht 2015 & $\begin{array}{l}\text { Bundesministerium für Europa, Integration und Äußeres, } \\
2015\end{array}$ \\
\hline DOC AT18 & Zusammen Österreich & Staatssekretariat für Integration, 2013 \\
\hline DOC AT13 & $\begin{array}{l}50 \text { Punkte - Plan zur Integration von Asylberechtigten } \\
\text { und subsidiär Schutzberechtigten in Österreich }\end{array}$ & $\begin{array}{l}\text { Bundesministerium für Europa, Integration und Äußeres, } \\
2015\end{array}$ \\
\hline DOC AT14 & Gesamtübersicht Förderungen 2015 & $\begin{array}{l}\text { Bundesministerium für Europa, Integration und Äußeres, } \\
2015\end{array}$ \\
\hline DOC AT15 & Datenbank „Integrationsprojekte in Österreich“ & $\begin{array}{l}\text { Staatssekretariat für Integration bzw. } \\
\text { Bundesministerium für Europa, Integration und Äußeres, } \\
\text { 2011-2016 }\end{array}$ \\
\hline DOC AT16 & Dialogforum Islam - Ergebnisse aus dem ersten Jahr & Bundesministerium für Inneres, 2013 \\
\hline DOC AT17 & Dialogforum Islam - Grundlagentexte & Bundesministerium für Inneres, 2013 \\
\hline DOC AT18 & Dialogforum Islam - Bericht & Bundesministerium für Inneres, 2013 \\
\hline DOC DE1 & $\begin{array}{l}\text { Erklärung der Bundesregierung: Gutes } \\
\text { Zusammenleben - klare Regeln }\end{array}$ & Bundesregierung 2006 \\
\hline DOC DE3 & $\begin{array}{l}\text { Teilnehmerinnen/Teilnehmer am Integrationsgipfel } \\
2006\end{array}$ & Bundeskanzleramt, 2006 \\
\hline DOC DE2 & $\begin{array}{l}\text { Mitglieder des Beirates der Beauftragten der } \\
\text { Bundesregierung für Migration, Flüchtlinge und } \\
\text { Integration }\end{array}$ & $\begin{array}{l}\text { Beauftragte der Bundesregierung für Migration, } \\
\text { Flüchtlinge und Integration, } 2006\end{array}$ \\
\hline DOC DE4 & $\begin{array}{l}\text { Nationaler Integrationsplan - Neue Wege, neue } \\
\text { Chancen }\end{array}$ & $\begin{array}{l}\text { Beauftragte der Bundesregierung für Migration, } \\
\text { Flüchtlinge und Integration, } 2007\end{array}$ \\
\hline DOC DE5 & $\begin{array}{l}\text { Teilnehmerinnen/Teilnehmer am Integrationsgipfel } \\
2007\end{array}$ & Bundeskanzleramt, 2007 \\
\hline
\end{tabular}




\begin{tabular}{|c|c|c|}
\hline DOC DE6 & $\begin{array}{l}\text { Teilnehmerinnen/Teilnehmer am Integrationsgipfel } \\
2008\end{array}$ & Bundeskanzleramt 2008 \\
\hline DOC DE7 & 1. Fortschrittsbericht zum Nationalen Integrationsplan & Die Bundesregierung, 2008 \\
\hline DOC DE8 & $\begin{array}{l}\text { Der Nationale Integrationsplan - Neue Wege, neue } \\
\text { Chancen-Beispiele des Erfolgs }\end{array}$ & $\begin{array}{l}\text { Beauftragte der Bundesregierung für Migration, } \\
\text { Flüchtlinge und Integration, } 2008\end{array}$ \\
\hline DOC DE9 & $\begin{array}{l}\text { Teilnehmerinnen/Teilnehmer am Integrationsgipfel } \\
2010\end{array}$ & Bundesregierung 2010 \\
\hline DOC DE10 & Nationaler Aktionsplan Integration & $\begin{array}{l}\text { Beauftragte der Bundesregierung für Migration, } \\
\text { Flüchtlinge und Integration, } 2011\end{array}$ \\
\hline DOC DE11 & $\begin{array}{l}\text { Teilnehmerinnen/Teilnehmeram Integrationsgipfel } \\
2012\end{array}$ & Bundesregierung 2012 \\
\hline DOC DE12 & $\begin{array}{l}\text { Datenbank: Auskunftssystems des Bundesamtes für } \\
\text { Migration und Flüchtlinge }\end{array}$ & Bundesamt für Migration und Flüchtlinge, 2016 \\
\hline DOC DE13 & Projektjahrbuch 2009 & Bundesamt für Migration und Flüchtlinge, 2009 \\
\hline DOC DE14 & Projektjahrbuch 2010 & Bundesamt für Migration und Flüchtlinge, 2010 \\
\hline DOC DE15 & Projektjahrbuch 2011 & Bundesamt für Migration und Flüchtlinge, 2011 \\
\hline DOC DE16 & Projektjahrbuch 2012 & Bundesamt für Migration und Flüchtlinge, 2012 \\
\hline DOC DE17 & Projektjahrbuch 2013 & Bundesamt für Migration und Flüchtlinge, 2013 \\
\hline DOC DE18 & Projektjahrbuch 2014 & Bundesamt für Migration und Flüchtlinge, 2014 \\
\hline DOC DE19 & Deutsche Islamkonferenz -Ergebnisse 3. Plenum 2008 & Deutsche Islam Konferenz 2008 \\
\hline DOC DE20 & Deutsche Islamkonferenz -Ergebnisse 4. Plenum 2009 & Deutsche Islam Konferenz 2009 \\
\hline DOC DE21 & Drei Jahre Deutsche Islam Konferenz 2009 & Deutsche Islam Konferenz 2009 \\
\hline DOC DE22 & Arbeitsprogramm der DIK in ihrer zweiten Phase & Deutsche Islam Konferenz 2010 \\
\hline DOC DE23 & Arbeitsprogramm & Deutsche Islam Konferenz 2014 \\
\hline DOC DE24 & Teilnehmerliste Lenkungsausschuss 1 & Deutsche Islam Konferenz 2015 \\
\hline DOC DE25 & Tagesordnung Lenkungsausschuss 1 & Deutsche Islam Konferenz 2015 \\
\hline DOC DE26 & Tagesordnung Lenkungsausschuss 2 & Deutsche Islam Konferenz 2015 \\
\hline DOC DE27 & Teilnehmerliste Lenkungsausschuss 2 & Deutsche Islam Konferenz 2015 \\
\hline $\mathrm{DOC} \mathrm{CH} 1$ & $\begin{array}{l}\text { Integrationsförderung des Bundes: Evaluation des } \\
\text { Schwerpunkteprogramms } 2004-2007\end{array}$ & Eidgenössische Kommission für Migrationsfragen, 2008 \\
\hline $\mathrm{DOC} \mathrm{CH} 2$ & Umsetzung Massnahmenpaket Integration 2008 & $\begin{array}{l}\text { Interdepartementalen Arbeitsgruppe Migration IAM, } \\
2008\end{array}$ \\
\hline $\mathrm{DOC} \mathrm{CH3}$ & Umsetzung Massnahmenpaket Integration 2009 & $\begin{array}{l}\text { Interdepartementalen Arbeitsgruppe Migration IAM, } \\
2009\end{array}$ \\
\hline $\mathrm{DOC} \mathrm{CH} 4$ & Umsetzung Massnahmenpaket Integration 2010 & $\begin{array}{l}\text { Interdepartementalen Arbeitsgruppe Migration IAM, } \\
2010\end{array}$ \\
\hline $\mathrm{DOC} \mathrm{CH} 5$ & $\begin{array}{l}\text { Integrationsförderung des Bundesund ihre } \\
\text { Auswirkungen in den Kantonen - Jahresbericht } 2008\end{array}$ & $\begin{array}{l}\text { Eidgenössisches Justiz- und Polizeidepartment/ } \\
\text { Bundesamt für Migration } 2008\end{array}$ \\
\hline $\mathrm{DOC} \mathrm{CH} 6$ & $\begin{array}{l}\text { Integrationsförderung des Bundesund ihre } \\
\text { Auswirkungen in den Kantonen - Jahresbericht } 2009\end{array}$ & $\begin{array}{l}\text { Eidgenössisches Justiz- und Polizeidepartment/ } \\
\text { Bundesamt für Migration } 2009\end{array}$ \\
\hline $\mathrm{DOC} \mathrm{CH7}$ & $\begin{array}{l}\text { Integrationsförderung des Bundesund ihre } \\
\text { Auswirkungen in den Kantonen - Jahresbericht } 2010\end{array}$ & $\begin{array}{l}\text { Eidgenössisches Justiz- und Polizeidepartment/ } \\
\text { Bundesamt für Migration } 2010\end{array}$ \\
\hline
\end{tabular}




\begin{tabular}{|c|c|c|}
\hline $\mathrm{DOC} \mathrm{CH8}$ & $\begin{array}{l}\text { Integrationsförderung des Bundesund ihre } \\
\text { Auswirkungen in den Kantonen - Jahresbericht } 2011\end{array}$ & $\begin{array}{l}\text { Eidgenössisches Justiz- und Polizeidepartment/ } \\
\text { Bundesamt für Migration } 2011\end{array}$ \\
\hline $\mathrm{DOC} \mathrm{CH} 9$ & $\begin{array}{l}\text { Integrationsförderung des Bundesund ihre } \\
\text { Auswirkungen in den Kantonen - Jahresbericht } 2012\end{array}$ & $\begin{array}{l}\text { Eidgenössisches Justiz- und Polizeidepartment/ } \\
\text { Bundesamt für Migration } 2012\end{array}$ \\
\hline $\mathrm{DOC} \mathrm{CH} 10$ & Anhang zum Jahresbericht 2012 & $\begin{array}{l}\text { Eidgenössisches Justiz- und Polizeidepartment/ } \\
\text { Bundesamt für Migration } 2013\end{array}$ \\
\hline $\mathrm{DOC} \mathrm{CH} 11$ & $\begin{array}{l}\text { Integrationsförderung des Bundesund ihre } \\
\text { Auswirkungen in den Kantonen - Jahresbericht } 2013\end{array}$ & $\begin{array}{l}\text { Eidgenössisches Justiz- und Polizeidepartment/ } \\
\text { Bundesamt für Migration } 2013\end{array}$ \\
\hline $\mathrm{DOC} \mathrm{CH} 12$ & Anhang zum Jahresbericht 2013 & $\begin{array}{l}\text { Eidgenössisches Justiz- und Polizeidepartment/ } \\
\text { Bundesamt für Migration } 2013\end{array}$ \\
\hline $\mathrm{DOC} \mathrm{CH13}$ & $\begin{array}{l}\text { Liste der Programme und Projekte von nationaler } \\
\text { Bedeutung des Bundes }\end{array}$ & Staatssekretariat für Migration 2014 \\
\hline DOC CH14 & Bericht KIP 2014 & Staatssekretariat für Migration 2014 \\
\hline DOC CH15 & Citoyennité auf den Punkt gebracht & Eidgenössische Kommission für Migrationsfragen, 2015 \\
\hline DOC CH16 & $\begin{array}{l}\text { Bericht des Bundesrates über die Situation der } \\
\text { Muslime in der Schweiz }\end{array}$ & Der Bundesrat, 2010 \\
\hline DOC CH17 & Muslime in der Schweiz & Eidgenössische Kommission für Migrationsfragen, 2010 \\
\hline $\mathrm{DOC} \mathrm{CH} 18$ & $\begin{array}{l}\text { Muslim-Dialog 2010: Austausch zwischen den } \\
\text { Bundesbehörden und Musliminnen und Muslimen in } \\
\text { der Schweiz }\end{array}$ & Eidgenössisches Justiz- und Polizeidepartment 2011 \\
\hline
\end{tabular}

\section{Appendix 2}

\begin{tabular}{|c|c|c|}
\hline \multicolumn{3}{|l|}{ Structure Codebook } \\
\hline \multirow{8}{*}{$\begin{array}{l}\text { Analysing governance } \\
\text { (following Bader 2007a) }\end{array}$} & \multirow[t]{3}{*}{ key figures } & document/speake \\
\hline & & when/where \\
\hline & & who \\
\hline & \multicolumn{2}{|l|}{ measure/idea } \\
\hline & \multirow[t]{3}{*}{ target (subjects) } & at whom \\
\hline & & via \\
\hline & & for/against whom \\
\hline & \multicolumn{2}{|l|}{ means } \\
\hline \multirow{10}{*}{$\begin{array}{l}\text { Analysing governmentality (following } \\
\text { Bacchi 2009) }\end{array}$} & \multicolumn{2}{|l|}{ concern } \\
\hline & \multicolumn{2}{|l|}{ cause } \\
\hline & \multicolumn{2}{|c|}{ underlying assumptions } \\
\hline & \multicolumn{2}{|c|}{ emergence of this problem representations } \\
\hline & \multicolumn{2}{|c|}{ techniques of problem solving } \\
\hline & \multicolumn{2}{|c|}{ alternative problem formulation/ what is left unsaid } \\
\hline & \multirow[t]{3}{*}{ effects } & direct \\
\hline & & subjectification \\
\hline & & discursive \\
\hline & \multicolumn{2}{|c|}{ perspectives that emerge } \\
\hline
\end{tabular}


Appendix 3

\begin{tabular}{|c|c|c|c|}
\hline Interview & Name & Function & Date/place \\
\hline INT AT1 & Martin Kienl & Bundesministerium für Europa, Integration und Äußeres & 02/15/15, Vienna \\
\hline INT AT2 & Carla A. Baghajati & Islamische Glaubensgemeinschaft in Österreich & 08/31/16, Vienna \\
\hline INT AT3 & Rainald Tippow & Erzdiözese Wien & 26/09/16 Vienna \\
\hline INT DE1 & Zekeriya Altuğ & DITIB/Koordinationsrat der Muslime in Deutschland & 08/05/16, Cologne \\
\hline INT DE2 & Murat Gümüs & Islamrat für die Bundesrepublik Deutschland & 08/04/16, Cologne \\
\hline INT DE3 & N.N. & (Muslim association preferring anonymity) & 08/05/16 Cologne \\
\hline INT DE4 & Aiman A. Mazyek & Zentralrat der Muslime in Deutschland & 08/03/16, Telephone \\
\hline INT DE5 & Honey Deihimi & $\begin{array}{l}\text { Arbeitsstab der Beauftragten der Bundesregierung für } \\
\text { Migration, Flüchtlinge und Integration }\end{array}$ & 08/08/16, Berlin \\
\hline INT DE6 & Reinhard Busch & Bundesministerium des Inneren & 08/09/16, Berlin \\
\hline INT DE7 & Kerstin Düsch & Katholisches Büro in Berlin & 08/09/16, written \\
\hline INT DE8 & Martin Dutzmann & Beauftragter der Evangelischen Kirche & 08/17/16, Telephone \\
\hline INT CH1 & Regula Zürcher Borlat & Staatssekretariat für Migration & 08/11/16, Bern \\
\hline INT CH2 & Lilo Roost Vischer & Religionsbeauftragte Kanton Basel & 08/10/16, Basel \\
\hline INT CH3 & Montassar BenMrad & Föderation islamischer Dachorganisationen der Schweiz & 08/10/16, Zürich \\
\hline INT CH4 & Samuel Behloul & Migratio - Katholische Bischofskonferenz & 08/11/16, Freiburg \\
\hline INT CH5 & Laila Oulouda & Presidentin Iman-Zentrum & 08/12/16, Volketswil \\
\hline INT CH6 & Simon Röthlisberger & Schweizerischer Evangelischer Kirchenbund & 08/30/16, Telephone \\
\hline
\end{tabular}


